\section{Temporal Relationship between Calcium and Fruit Growth and Development in Bell Pepper (Capsicum} annuum L.)

\author{
Andrés Mayorga-Gómez, Savithri U. Nambeesan, and Timothy Coolong \\ Department of Horticulture, University of Georgia, 120 Carlton Street, \\ Athens, GA 30602
}

Juan Carlos Díaz-Pérez

Department of Horticulture, University of Georgia, 2360 Rainwater Road, Tifton, GA 31793

Additional index words. blossom-end rot, fruit development, nutrition

\begin{abstract}
Bell peppers (Capsicum annuum $\mathrm{L}$.) are ranked eighth in value for vegetable production in the United States (USDA-NASS, 2019). Due to the high value of bell peppers, disorders such as blossom-end rot (BER) can cause significant losses in yield by up to $35 \%$ for growers. BER is the symptom of a calcium $\left(\mathrm{Ca}^{2+}\right)$ deficiency that may occur during periods of cell expansion when the supply of $\mathrm{Ca}^{2+}$ may be lower than demand. In this study, we determined the temporal patterns of the fruit $\mathrm{Ca}^{2+}$ concentration $\left(\left[\mathrm{Ca}^{2+}\right]\right)$ and accumulation in three separate studies under field and greenhouse conditions. In the three experiments, $\left[\mathrm{Ca}^{2+}\right]$ during fruit development showed varied patterns: it remained constant, decreased transiently during the cell expansion phase, or displayed a more gradual sustained decrease. However, in the three experiments, fruit $\mathrm{Ca}^{2+}$ accumulation increased during development as fruit size increased. In two experiments, the distal part of the fruit had lower $\left[\mathrm{Ca}^{2+}\right]$ than the proximal end. However, there was no correlation between $\left[\mathrm{Ca}^{2+}\right]$ in various fruit sections with BER incidence. Seeds and placental tissue had increased $\left[\mathrm{Ca}^{2+}\right]$ and several other macro- and micronutrients; this spatial distribution of $\mathrm{Ca}^{2+}$ coupled with subcellular $\mathrm{Ca}^{2+}$ distribution should be explored in future studies. The temporal pattern of $\mathrm{Ca}^{2+}$ accumulation in this study suggests that fruit $\mathrm{Ca}^{2+}$ uptake continues throughout fruit development. Therefore, $\mathrm{Ca}^{2+}$ application during bloom and early fruit development may prevent or minimize $\mathrm{Ca}^{2+}$ deficiency disorders in bell pepper.
\end{abstract}

Calcium $\left(\mathrm{Ca}^{2+}\right)$ is an essential macronutrient in plants. It has important roles in providing structural stability to cell walls and membranes and as a secondary messenger in cellular signaling (White and Broadley, 2003). Acquisition of $\mathrm{Ca}^{2+}$ by roots and its transport to the shoot are determined by environmental and physiological factors that affect the uptake of water and nutrients into the xylem (Gilliham et al., 2011; Hocking et al., 2016). For example, higher canopy transpiration rates compared with that of the fruit can preferentially favor xylem flow and $\mathrm{Ca}^{2+}$ partitioning to the leaves rather than to

Received for publication 28 Jan. 2020. Accepted for publication 6 Apr. 2020.

Published online 11 May 2020.

This publication was supported by the U.S. Department of Agriculture's (USDA) Agricultural Marketing Service through grant 16SCBGPGA0010. Its contents are solely the responsibility of the authors and do not necessarily represent the official views of the USDA.

S.U.N. is the corresponding author. E-mail: sunamb@ uga.edu.

This is an open access article distributed under the CC BY-NC-ND license (https://creativecommons. org/licenses/by-nc-nd/4.0/). the fruit (Adams and Ho, 1993; Ho, 1989; Hocking et al., 2016). Under such conditions, fruits can be susceptible to $\mathrm{Ca}^{2+}$ deficiency disorders such as bitter pit in apple and BER in peppers, tomatoes, and watermelons (Gilliham et al., 2011; White and Broadley, 2003). Initiation of BER often occurs in the distal portion of the fruit as water-soaked spots that eventually develop into brown necrotic areas that are sometimes localized, internalized, or span the entire fruit (Adams and Ho, 1993; Ho and White, 2005; Morley et al., 1993; Spurr, 1959). The symptoms of BER appear during the cell expansion phase of fruit growth between 14 and $25 \mathrm{~d}$ after anthesis, at a time when higher $\left[\mathrm{Ca}^{2+}\right]$ may be necessary to sustain accelerated fruit growth (Belda and Ho, 1993; Marcelis and Ho, 1999; Rubio et al., 2009). Therefore, the inability to transport adequate $\mathrm{Ca}^{2+}$ to developing fruit may trigger BER development (Ho et al., kiwi, $\approx 80 \%$ of mature fruit $\mathrm{Ca}^{2+}$ content accumulates during early fruit growth $\approx 5$ to 8 weeks after bloom (Ferguson and Watkins, 1989; Montanaro et al., 2006, 2010). However, $\mathrm{Ca}^{2+}$ uptake rates differ during development among apples, kiwi, and grapes (Casero et al., 2017; Montanaro et al., 2012; 1993). In fruits such as apricot, apples, and
Rogiers et al., 2006), with some recent evidence suggesting the importance of phloem for fruit $\mathrm{Ca}^{2+}$ uptake (Song et al., 2018).

Even though multiple studies have indicated $\mathrm{Ca}^{2+}$ deficiency to be causal in BER development, $\mathrm{Ca}^{2+}$ concentrations in BERaffected fruit are sometimes similar to or higher than those in non-BER fruit (Hagassou et al., 2019; Ho and White, 2005; Nonami et al., 1995; Saure, 2001). Despite these correlation discrepancies, soil and foliar applications of $\mathrm{Ca}^{2+}$ have been shown to alleviate BER symptoms (Taylor and Locascio, 2004). Therefore, the timing of $\mathrm{Ca}^{2+}$ availability in relation to fruit development and the spatial dynamics of $\mathrm{Ca}^{2+}$ accumulation may be important factors associated with BER development. In this study, we determined $\left[\mathrm{Ca}^{2+}\right]$ and its accumulation at various stages during bell pepper fruit growth and development. Furthermore, we also quantified $\left[\mathrm{Ca}^{2+}\right]$ in apical, mid, and basal sections of the fruit. Data presented here provide the foundation for a better understanding of the temporal and spatial relationships between $\left[\mathrm{Ca}^{2+}\right]$ during bell pepper fruit growth and development.

\section{Materials and Methods}

Field and greenhouse growing conditions. Fruit were collected from three separate experiments: field experiments in 2017 and 2018 and a greenhouse experiment in 2018 . In 2017, fruit were collected from commercial fields located near Moultrie, GA and the University of Georgia Tifton Vegetable Park in Tifton; however, in 2018, fruit were collected only from the latter field.

In Spring 2017, 'PS09979325' (Seminis, St. Louis, MO) fruit were collected from three commercial fields (three replicates) at the same farm located near Moultrie, GA. The soil was primarily a Dothan loamy sand with $0 \%$ to $2 \%$ slope. These soils are predominately sandy and well-drained. Plants were grown according to standard practices for the region: on raised beds with black plastic mulch and drip irrigation. Rows of plastic had $1.8-\mathrm{m}$ spacing and plants situated on double rows on plastic with $30.5 \mathrm{~cm}$ inrow spacing and $45.7 \mathrm{~cm}$ between rows on a single bed of plastic. Preplant fertilization was dependent on the soil tests for the fields; all fields received $\approx 56 \mathrm{~kg} / \mathrm{ha} \mathrm{N}$ preplant fertilizer using a custom fertilizer blend for the field. Preplant soil $\mathrm{pH}$ ranged from 6.0 to 6.8 for all fields. Preplant soil $\mathrm{Ca}^{2+}$ levels ranged from 1120.9 to $2017.5 \mathrm{~kg} / \mathrm{ha}$ (Mehlich 3; Waters Agricultural Laboratory, Camilla, GA); these levels were sufficient for the production of bell peppers in Georgia. Current recommendations require additional calcium if soil test levels are less than 896 $\mathrm{kg} \cdot \mathrm{ha}^{-1}$ (Kissel and Sonon, 2008). Fertigation was performed at least three times per week using 7-0-7 liquid fertilizer (Ellenton Ag. Services, Ellenton, GA). Seasonal total N fertilization ranged from 224.2 to $252.2 \mathrm{~kg} / \mathrm{ha}$ $\mathrm{N}$. The average precipitation at this location was $3.8 \mathrm{~mm}$. 
In Spring 2017 and 2018, fruit were also collected from seven and two varieties, respectively, from the University of Georgia Tifton Vegetable Park in Tifton, GA (lat. $31^{\circ} 5^{\prime} \mathrm{N}$, long. $\left.83^{\circ} 5^{\prime} \mathrm{W}\right)$. The soil is a Tifton loamy sand series ( $0 \%$ to $2 \%$ slope). In 2017 , soils were fumigated with dimethyl disulfide (500 kg/ha) and chloropicrin (133.4 kg/ha, Paladin PIC-21; TriEst Ag Group Inc., Tifton, GA) and, in 2018, soils were fumigated with chloropicrin $(217.5 \mathrm{~kg} / \mathrm{ha}), 1,3$-dichloropropene (144.6 kg/ha; Pic-Chlor 60; TriEst Ag Group Inc.) when plastic was laid. Irrigation in both years was supplied with a single line of drip irrigation tubing (30.5-cm emitter spacing, $31.6 \mathrm{~mL} / \mathrm{s}$ per 30.5 at $69 \mathrm{kPa}$, Chapin DLX; Jain USA Inc., Haines City, FL). Beds were $15.2-\mathrm{cm}$-tall by $81.3-\mathrm{cm}$-wide spaced on $1.83-\mathrm{m}$ row centers covered with a 27.3 $\mu \mathrm{m}$-thick totally impermeable film plastic mulch (Vaporsafe RM, TIF, 1.5-m; Raven Industries, Sioux Falls, SD). In 2017, a preplant homogenized fertilizer consisting of 56 $\mathrm{kg} / \mathrm{h} \mathrm{N}(5.0 \mathrm{~N}-4.3 \mathrm{P}-12.5 \mathrm{~K}$; Rainbow Plant Food, Agrium, Tifton, GA) was placed in the row immediately before laying plastic mulch and incorporated when the raised bed was formed. In 2018, preplant homogenized fertilizer consisting of $56 \mathrm{~kg} / \mathrm{h} \mathrm{N}(10.0 \mathrm{~N}-4.3 \mathrm{P}$ 8.3K; Rainbow Plant Food, Agrium) was used. The $(5.0 \mathrm{~N}-4.3 \mathrm{P}-12.5 \mathrm{~K})$ fertilizer was composed of $4.5 \%$ ammoniacal nitrogen and $0.5 \%$ nitrate nitrogen, whereas the $(10.0 \mathrm{~N}-$ $4.3 \mathrm{P}-8.3 \mathrm{~K}$ ) fertilizer was composed of $9.5 \%$ ammoniacal nitrogen and $0.5 \%$ nitrate nitrogen. Nitrogen and phosphate in both fertilizers were derived from ammonium nitrate, ammonium sulfate, and ammonium phosphate. Less preplant potassium was applied in 2018 due to a higher soil test potassium value. No $\mathrm{Ca}^{2+}$ was present in the preplant fertilizer. Eight-week-old bell pepper seedlings were transplanted on 16 Mar. 2017 and 5 Apr. 2018 in a double row configuration on each plastic bed. In 2017, plots contained 40 plants each; however, in 2018, plots contained 30 plants. Three and four replicates (plots) per variety were arranged in a randomized complete block design in 2017 and 2018 , respectively. Irrigation was applied at $\approx 2.5$ to $3.8 \mathrm{~cm}$ weekly. During the season, weekly applications of 4-0-8 liquid fertilizer (4N-0P-6.4K; Big Bend Supply Co Inc., Cairo, GA) were applied at a rate of 13.5 $\mathrm{kg} / \mathrm{ha} \mathrm{N}$ for a season total application of $217.5 \mathrm{~kg} / \mathrm{ha} \mathrm{N}$. The $4-0-8$ liquid fertilizer contained $2.4 \%$ nitrate- $\mathrm{N}, 0.5 \%$ ammonium$\mathrm{N}$, and $1.0 \%$ urea-N $(3.9 \% \mathrm{~N})$. Seasonal total $\mathrm{N}$ fertilization was $\approx 217 \mathrm{~kg} / \mathrm{ha} \mathrm{N}$. In both years, bell pepper plants were staked and strung $\approx 3$ to 4 weeks after planting using standard practices for the region (Vegetable Crop Handbook for Southeastern United States, 2017). Fungicides and insecticides were applied weekly according to commercial recommendations for bell pepper grown in Georgia (Horton, 2016). The average precipitation at this location was 3.2 in 2017 and $4.4 \mathrm{~mm}$ in 2018.

In 2018, bell pepper var. Aristotle (Seminis, St. Louis, MO) was grown from Dec.
2017 to May 2018 in Athens, GA, in a greenhouse with minimum and maximum temperatures of 15 and $29{ }^{\circ} \mathrm{C}$, respectively. The relative humidity was $66 \%$. Initially, seeds were germinated in plug nursery trays in a Low Temperature Incubator Model 2015 (VWR International, Randor, PA) at $25{ }^{\circ} \mathrm{C}$ with $12 \mathrm{~h}$ of light and dark. Subsequently, the seedlings were transplanted in Fafard 3B Mix Metro-Mix 830 (Sun Gro, Agawam, MA) in an 11.5-L plastic nursery container. Pots were arranged in a completely randomized design with four replicates. Plants were irrigated weekly using a fertilizer that contained no $\mathrm{Ca}^{2+}$ according to the manufacturer's label (Jack's Classic All Purpose 20-20-20; JR Peters Inc., Allentown, PA).

$\left[\mathrm{Ca}^{2+}\right]$ and accumulation during fruit growth and development. In 2017, 'PS09979325' green fruit of varying size were harvested from three commercial fields at Moultrie, GA. Harvested fruit were grouped based on their diameter to represent different developmental fruit stages. $\left[\mathrm{Ca}^{2+}\right]$ analyses were performed for five developmental groups: group 1,10 to $15 \mathrm{~mm}(\mathrm{n}=20)$; group 2, 20 to $30 \mathrm{~mm}(\mathrm{n}=15)$; group 3, 40 to $60 \mathrm{~mm}(\mathrm{n}=$ 6); group 4, 70 to $80 \mathrm{~mm}(\mathrm{n}=6)$; and group 5 , larger than $80 \mathrm{~mm}(\mathrm{n}=6)$. In 2018, fruit from 'PS09979325' and 'Aristotle' were collected from the Tifton Vegetable Park in Tifton, GA. A total elemental analysis in 2018 was performed for the five groups described in the 2017 experiment, except that group 1 consisted of 20 fruit with a diameter of 10 to $20 \mathrm{~mm}$. An additional modification included using only the pericarp tissue (to obtain tissue-specific resolution) after removal of the placental tissue and seeds. In the greenhouse experiment, flowers were tagged and manually pollinated, and fruit were collected from four replicates at $14 \mathrm{~d}$ after anthesis (DAA), 21 DAA, 28 DAA, and at ripening. Fruit were considered ripe when the color turned completely red and, therefore, had variable DAA. Similar to 2018, an elemental analysis was performed only for the pericarp tissue (after removing the internal placental tissue and seeds).

$\left[\mathrm{Ca}^{2+}\right]$ in fruit sections. In 2017, seven varieties, Prowler (HM Clause, Davis, CA), Seedway 48 (Seedway, Hall, NY), Aristotle, Antebellum, PS09979325, Green Machine, and SV3255PB (Seminis, St. Louis, MO) were harvested from Tifton Vegetable Park, Tifton. In 2018, 'Aristotle' and 'PS09979325' were harvested from Tifton Vegetable Park, Tifton. To quantify $\left[\mathrm{Ca}^{2+}\right]$ in various sections of the fruit, five marketable mature green fruit per replicate from each variety were randomly chosen with a total of three and four replicates in 2017 and 2018, respectively. In 2017, each fruit was divided into three sections of approximately the same size; proximal, middle, and distal and $\left[\mathrm{Ca}^{2+}\right]$ analyses were performed for the three sections (pericarp and placental tissue together). In the 2018 field study, fruit were divided into three sections, similar to that in 2017. However, an elemental analysis was performed only using the pericarp tissue (after removal of placenta and seeds). In the greenhouse, at $28 \mathrm{DAA}$ and the ripe stage, fruit were separated into three sections and elemental analyses were performed separately for both the pericarp and internal fruit tissues (placenta and seeds).

$\mathrm{Ca}^{2+}$ and elemental analysis. For all experiments, fruit were dried at $60{ }^{\circ} \mathrm{C}$. In the 2017 field experiment, samples were analyzed for only $\mathrm{Ca}^{2+}$ (Waters Agricultural Laboratories, Inc.). In the 2018 field and greenhouse experiments, elemental analyses were performed by Agricultural and Environmental Service Laboratories (AESL) located at the University of Georgia, Athens, GA. The amount of $\mathrm{Ca}^{2+}$ per fruit was calculated by multiplying the $\left[\mathrm{Ca}^{2+}\right]$ by the dry weight and dividing it by the total number of fruits.

Statistical analyses involving a one-way analysis of variance for a completely randomized design for all experiments were performed using JMP Pro 14 (SAS Institute, Cary, NC). Means were separated using Tukey's honestly significant difference (HSD) test $(\alpha=0.05)$. Regression analyses were performed using Sigmaplot 11 (Systat Software 269 Inc., San Jose, CA).

BER incidence and correlation analyses. In the 2017 field experiment, BER was calculated for the seven varieties listed previously in the Materials and Methods $\left(\left[\mathrm{Ca}^{2+}\right]\right.$ in fruit sections). Each variety was harvested three times during the growing season. For each harvest, fruit were collected in three replicates. BER incidence was calculated based on the number of fruit with BER symptoms divided by the total number of all fruit harvested. Correlations between the BER incidence and $\left[\mathrm{Ca}^{2+}\right]$ in the fruit were determined using Pearson correlation coefficients $(r)$ and JMP Pro 14 (SAS Institute, Cary, NC).

\section{Results}

Calcium concentration and accumulation during fruit development. In the 2017 and 2018 field experiments, fruit size classes were treated as equivalent to fruit developmental stages. In $2017,\left[\mathrm{Ca}^{2+}\right]$ in field-grown 'PS09979325' fruit was not different during fruit development, with an average concentration of $2.3 \mathrm{mg} / \mathrm{g}$ (Fig. 1A; Supplemental Fig. 1A). $\mathrm{Ca}^{2+}$ accumulated in fruit throughout fruit development; it was 3.3-fold higher in fruit with diameters of 70 to $80 \mathrm{~mm}$ compared with the previous stage and 1.8-fold higher in fruit with diameters larger than $80 \mathrm{~mm}$ compared with 70 - to $80-\mathrm{mm}$ fruit (Fig. 1B; Supplemental Fig. 1B). In 2018, $\left[\mathrm{Ca}^{2+}\right]$ levels were similar during the initial and final stages of fruit development and decreased in fruit with 20 - to $60-\mathrm{mm}$ diameters by 1.3-fold in 'PS09979325' (means not separable using Tukey's HSD, $\alpha=0.05$ ) and by 1.7-fold in 'Aristotle' (Fig. 2A and C; Supplemental Fig. 2A and C). Similar to 2017, the $\mathrm{Ca}^{2+}$ accumulation increased with fruit development: in 'PS09979325', it was 2.8 -fold higher in fruit with 70 - to $80-\mathrm{mm}$ 
diameters than the previous stage and 1.8fold higher in fruit with diameters larger than $80 \mathrm{~mm}$ compared with $70-$ to $80-\mathrm{mm}$ fruit (Fig. 2B; Supplemental Fig. 2B). In 'Aristotle', fruit $\mathrm{Ca}^{2+}$ increased by 5.9-, 1.8-, and 2.5-fold at successive developmental stages from 20 to $30 \mathrm{~mm}$ to larger than $80 \mathrm{~mm}$ (Fig. 2D; Supplemental Fig. 2D). In contrast to the field experiments, in the greenhouse, when fruit were individually tagged and

monitored during development, $\left[\mathrm{Ca}^{2+}\right]$ consistently decreased during fruit development from $1.5 \mathrm{mg} / \mathrm{g}$ at 14 DAA to $0.9 \mathrm{mg} / \mathrm{g}$ (1.7-fold) at $28 \mathrm{DAA}$, and to $0.7 \mathrm{mg} / \mathrm{g}(2.1$ fold) at ripening (Fig. 3A; Supplemental Fig. $3 \mathrm{~A}$ ). $\mathrm{Ca}^{2+}$ accumulation increased during fruit development and was three-fold higher at 28 DAA compared with 21 DAA (Fig. 3B; Supplemental Fig. 3B). Total fruit $\mathrm{Ca}^{2+}$ at the final developmental stage in
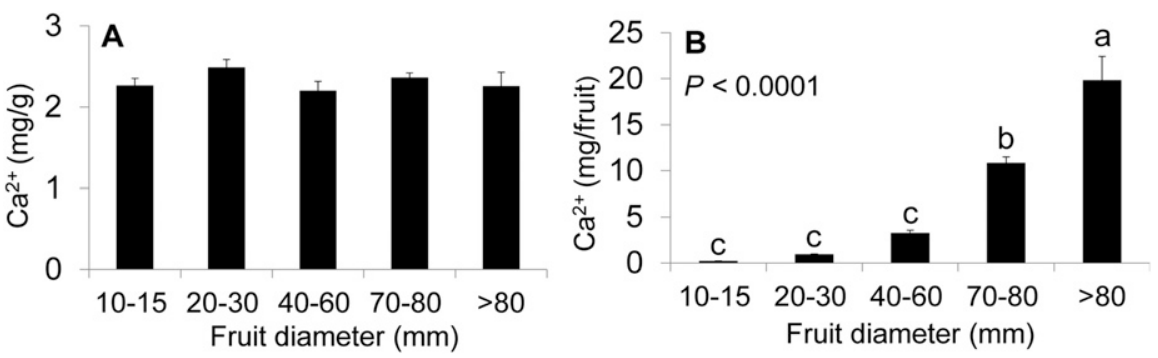

Fig. 1. Calcium concentration (A) and amount per fruit (B) in 2017 in field-grown variety 'PS09979325' during fruit development. Values are means and SE of three replicates. Means separation was performed using Tukey's honestly significant difference following a test of significance using an analysis of variance $(\alpha=0.05)$. Means followed by a different letter are significantly different.
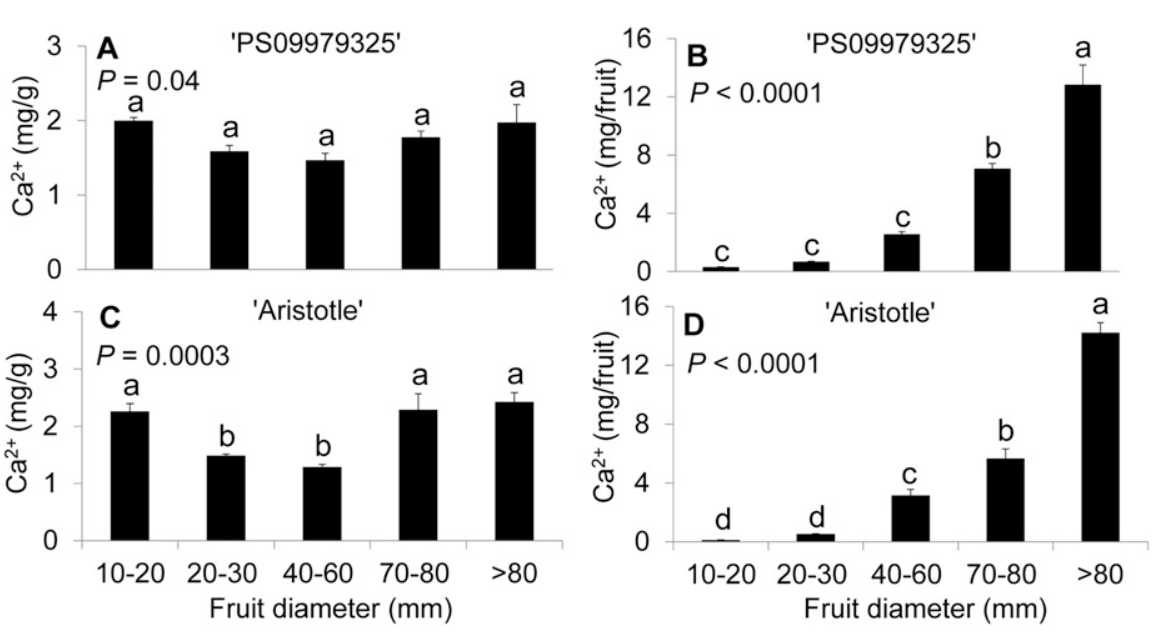

Fig. 2. Calcium concentration (A, C) and amount per fruit $(\mathbf{B}, \mathbf{D})$ in 2018 in field-grown variety 'PS09979325' (A, B) and 'Aristotle' (C, D) during fruit development. Values are means and SE of four replicates. Means separation was performed using Tukey's honestly significant difference following a test of significance using an analysis of variance $(\alpha=0.05)$. Means followed by a different letter are significantly different.

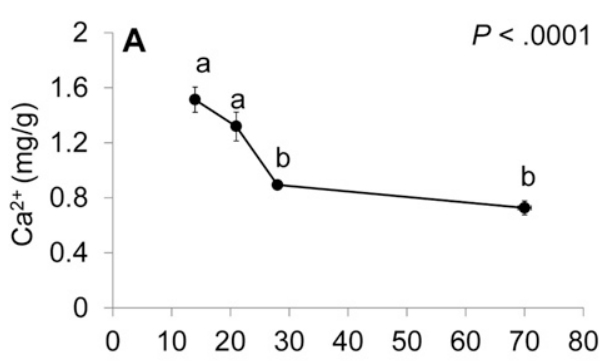

Days after anthesis

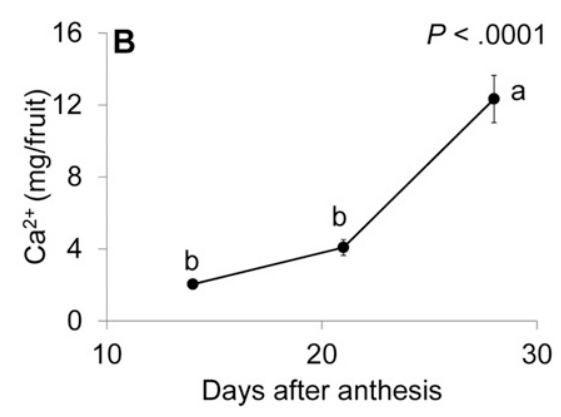

Fig. 3. Calcium concentration (A) and amount per fruit (B) in 2018 in greenhouse-grown variety 'Aristotle' during fruit development at various days after anthesis (DAA). Calcium concentration (A) in ripe fruit was harvested at different DAA, shown using X-error bars. Values are means and SE of four replicates. Means separation was performed using Tukey's honestly significant difference following a test of significance using an analysis of variance $(\alpha=0.05)$. Means followed by a different letter are significantly different.
'PS09979325' was $19.8 \mathrm{mg} /$ fruit and $12.8 \mathrm{mg}$ / fruit in the 2017 and 2018 field study, respectively, and $14.2 \mathrm{mg} /$ fruit and $12.3 \mathrm{mg}$ /fruit in 'Aristotle' in the 2018 field and greenhouse studies, respectively (Figs. 1B, 2B, 2D, 3B).

Elemental analyses during the 2018 field trial showed that [K] was similar during development in 'PS09979325' but increased in 'Aristotle' (Table 1). In 'PS09979325,' $[\mathrm{Mg}],[\mathrm{P}],[\mathrm{S}]$, and $[\mathrm{B}]$ decreased during the late developmental stages. However, in 'Aristotle,' in addition to these elements, [Fe], $[\mathrm{Cu}]$, and $[\mathrm{Mn}]$ showed a pattern similar to that of $\left[\mathrm{Ca}^{2+}\right]$, with higher concentrations at early and late developmental stages (Table 1). [N] decreased during development in both varieties (Table 1). However, in the greenhouse study, similar to $\left[\mathrm{Ca}^{2+}\right],[\mathrm{K}]$, $[\mathrm{Mg}],[\mathrm{P}],[\mathrm{S}],[\mathrm{B}],[\mathrm{Fe}],[\mathrm{Mn}]$, and $[\mathrm{Zn}]$ decreased during development, $[\mathrm{N}]$ decreased until 28 DAA and increased in ripe fruit, and [Na] increased until 28 DAA and then decreased in ripe fruit (Table 3). Similar to $\mathrm{Ca}^{2+}$, the amount of all elements increased in the fruit throughout fruit development in the field and greenhouse studies (Tables 2 and 4).

Calcium concentration in different sections of the fruit. In 2017, $\left[\mathrm{Ca}^{2+}\right]$ was measured at the proximal, mid, and distal sections of the fruit of seven varieties. There was no significant interaction between the variety and fruit sections. Fruit $\left[\mathrm{Ca}^{2+}\right]$ in the midsection was 1.2 -fold lower than that in the proximal section. However, fruit $\left[\mathrm{Ca}^{2+}\right]$ in the distal section was similar to that in proximal and midsections (Fig. 4A). In the 2018 field study, fruit $\left[\mathrm{Ca}^{2+}\right]$ was significantly different across the three sections. However, this was not statistically separable using Tukey's HSD ( $\alpha$ $=0.05)$. The trend indicated a decline in concentration in the distal section of the fruit by 1.3-fold compared with the proximal and midsection (Fig. 4B). In the greenhouse study with 'Aristotle', a clear trend in fruit $\left[\mathrm{Ca}^{2+}\right]$ across different sections was evident. At 28 DAA, compared with the proximal section, fruit $\left[\mathrm{Ca}^{2+}\right]$ declined by 4 -fold in the distal section (Fig. 5). At the ripe stage, both the mid and distal fruit sections displayed 1.4and 1.7-fold lower $\left[\mathrm{Ca}^{2+}\right]$, respectively, compared with the proximal section (Fig. 5). $\left[\mathrm{Ca}^{2+}\right.$ ] was highest in placenta and seed at the ripe stage, but it was similar to that in the proximal section at 28 DAA (Fig. 5).

In the 2018 field experiment, the macronutrient $[\mathrm{Mg}]$ and micronutrients $[\mathrm{B}],[\mathrm{Mn}]$, and $[\mathrm{Zn}]$ were highest in the distal section compared with the proximal section (Table 5). In the greenhouse study, $[\mathrm{Mg}]$ was highest in the distal section in ripe fruit, whereas $[\mathrm{K}],[\mathrm{P}]$, and $[\mathrm{S}]$ were highest in the distal section at both 28 DAA and ripe fruit compared with the proximal section (Table 6). Micronutrients $[\mathrm{B}],[\mathrm{Mn}],[\mathrm{Cu}]$, and $[\mathrm{Zn}]$ were highest in the distal section compared with the proximal section in the ripe fruit, whereas [Mn] was highest in the proximal section at 28 DAA (Table 6). Ripe fruit in the greenhouse trial had the highest $[\mathrm{Mg}],[\mathrm{P}],[\mathrm{N}],[\mathrm{S}],[\mathrm{Fe}]$, $[\mathrm{Na}]$, and $[\mathrm{Zn}]$ in the placenta and seed (Table 6).

Calcium concentration and BER incidence. Fruit $\left[\mathrm{Ca}^{2+}\right]$ in 'Prowler' was 
Table 1. Elemental concentration in 2018 in field-grown variety 'PS09979325' and 'Aristotle' during fruit developmental stages (fruit diameter in mm).

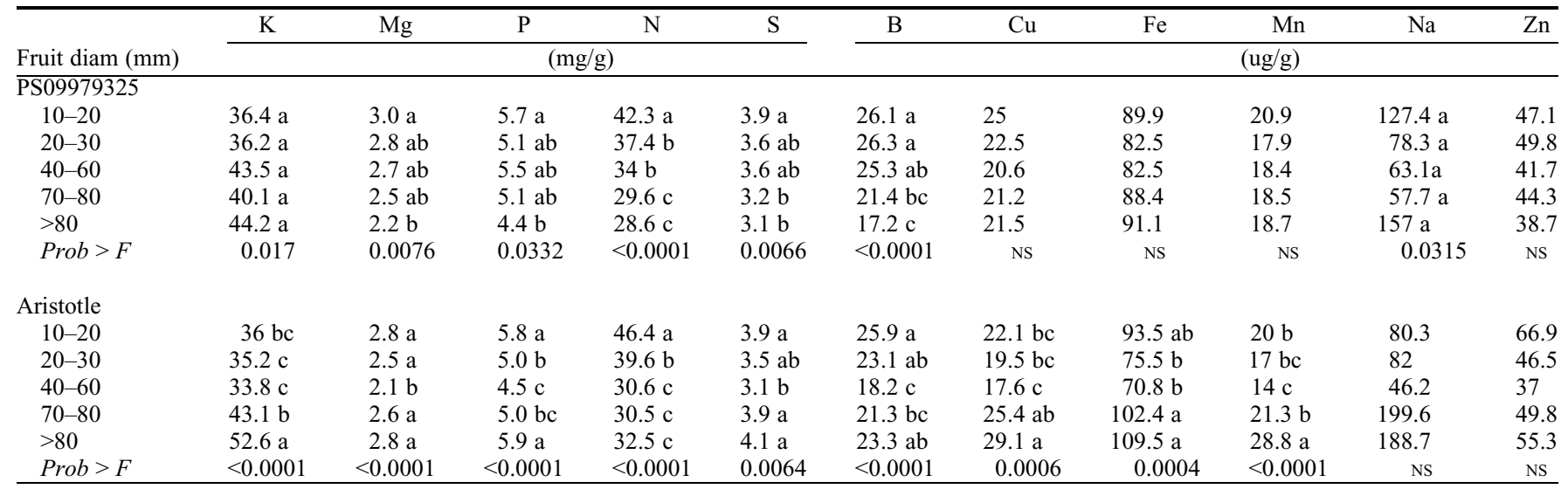

Values are means and SE of four replicates. Means separation was performed using Tukey's honestly significant difference following a test of significance using an analysis of variance $(\alpha=0.05)$. Means followed by a different letter are significantly different. NS $=$ nonsignificant.

Table 2. Elemental amount in 2018 in field-grown variety 'PS09979325' and 'Aristotle' during fruit developmental stages (fruit diameter in mm).

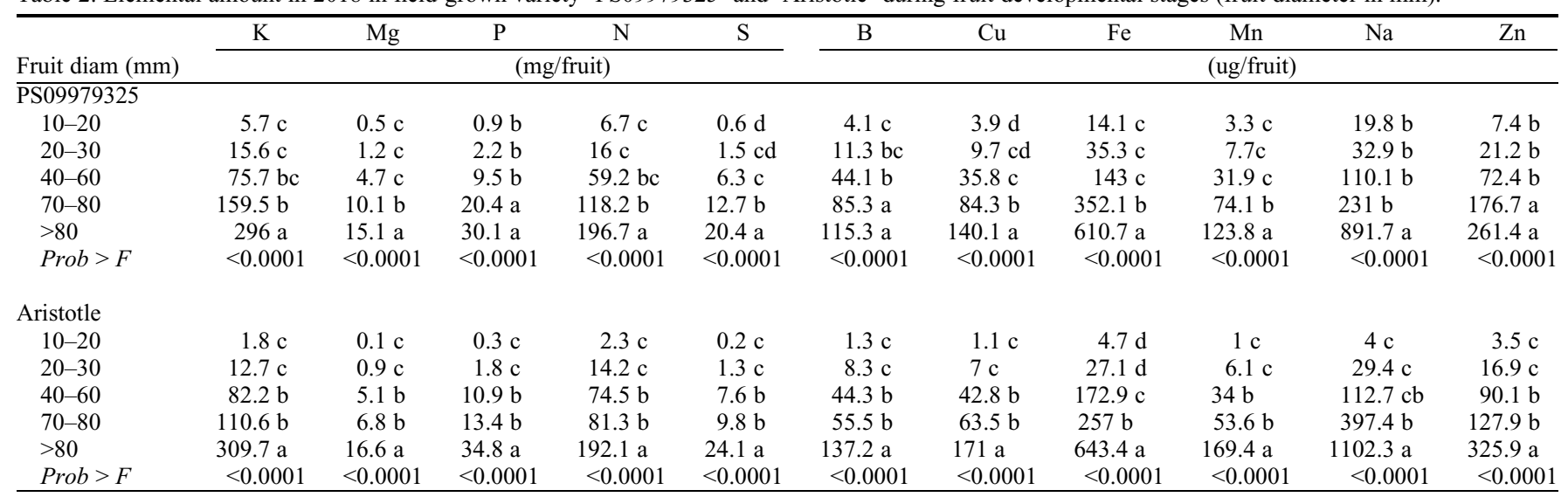

Values are means and SE of four replicates. Means separation was performed using Tukey's honestly significant difference following a test of significance using an analysis of variance $(\alpha=0.05)$. Means followed by a different letter are significantly different.

Table 3. Elemental concentration per fruit in 2018 in greenhouse-grown variety 'Aristotle' during fruit development at days after anthesis (DAA) and ripe stage.

\begin{tabular}{|c|c|c|c|c|c|c|c|c|c|c|c|}
\hline & $\mathrm{K}$ & $\mathrm{Mg}$ & $\mathrm{P}$ & $\mathrm{N}$ & $\mathrm{S}$ & B & $\mathrm{Cu}$ & $\mathrm{Fe}$ & $\mathrm{Mn}$ & $\mathrm{Na}$ & $\mathrm{Zn}$ \\
\hline Stages & & & $(\mathrm{mg} / \mathrm{g})$ & & & \multicolumn{6}{|c|}{ (ug/g) } \\
\hline $21 \mathrm{DAA}$ & $30.4 \mathrm{~b}$ & $2 \mathrm{~b}$ & $4.2 \mathrm{~b}$ & $22.9 \mathrm{~b}$ & $2.5 \mathrm{~b}$ & $22.8 \mathrm{~b}$ & 3.2 & $40.9 \mathrm{~b}$ & $25.1 \mathrm{ab}$ & $55.5 \mathrm{bc}$ & $22.8 \mathrm{~b}$ \\
\hline Prob $>F$ & $<0.0001$ & $<0.0001$ & $<0.0001$ & 0.0028 & $<0.0001$ & $<0.0001$ & 0.1312 & 0.0002 & 0.0004 & 0.0003 & 0.0012 \\
\hline
\end{tabular}

Elemental amount per fruit at ripe stage was not calculated because the total numbers of fruits were not recorded and are missing from the table. Values are means and SE of four replicates. Means separation was performed using Tukey's honestly significant difference following a test of significance using an analysis of variance $(\alpha=0.05)$. Means followed by a different letter are significantly different.

Table 4. Elemental amount per fruit in 2018 in greenhouse-grown variety 'Aristotle' during fruit development at days after anthesis (DAA) and ripe stage.

\begin{tabular}{|c|c|c|c|c|c|c|c|c|c|c|c|}
\hline & $\mathrm{K}$ & $\mathrm{Mg}$ & $\mathrm{P}$ & $\mathrm{N}$ & $\mathrm{S}$ & $\mathrm{B}$ & $\mathrm{Cu}$ & $\mathrm{Fe}$ & $\mathrm{Mn}$ & $\mathrm{Na}$ & $\mathrm{Zn}$ \\
\hline Stages & \multicolumn{5}{|c|}{ (mg/fruit) } & & \multicolumn{5}{|c|}{ (ug/fruit) } \\
\hline 21 DAA & $94.7 \mathrm{~b}$ & $6.2 \mathrm{~b}$ & $12.9 \mathrm{~b}$ & $70.9 \mathrm{~b}$ & $7.9 \mathrm{~b}$ & $70.7 \mathrm{~b}$ & $10 \mathrm{~b}$ & $127.5 \mathrm{~b}$ & $77.5 \mathrm{~b}$ & $171.6 \mathrm{~b}$ & $70.7 \mathrm{~b}$ \\
\hline
\end{tabular}

Elemental amount per fruit at ripe stage was not calculated because the total numbers of fruits were not recorded and are missing from the table. Values are means and SE of four replicates. Means separation was performed using Tukey's honestly significant difference following a test of significance using an analysis of variance $(\alpha=0.05)$. Means followed by a different letter are significantly different.

higher compared with the other varieties except in 'PS09979325' (Fig. 6A). The total amount of $\mathrm{Ca}^{2+}$ in the whole fruit, however, was not significantly different among varieties and ranged from 12 to $18 \mathrm{mg}$ /fruit (Fig. 6B). BER incidences in 'Aristotle', 'Antebellum', 'Prowler', 'PS09979325', 'SV3255PB', 'Green Machine', and 'Seedway 48' were
$8.9 \%, 8.7 \%, 10.4 \%, 14.9 \%, 16.0 \%, 19.0 \%$, and $29 \%$, respectively (Fig. 7). The BER incidence in 'Seedway 48' was higher than that of other varieties except 'Green 
Machine' (Fig. 7). The $\left[\mathrm{Ca}^{2+}\right]$ in whole fruit or various fruit sections did not correlate with the BER incidence (Table 7). Other correlations included a positive correlation between $\left[\mathrm{Ca}^{2+}\right]$ in the proximal, mid, and distal sections and total fruit $\left[\mathrm{Ca}^{2+}\right](r=$ $0.76,0.93$, and 0.87 , respectively), positive correlation of $\left[\mathrm{Ca}^{2+}\right]$ in the proximal section and the total amount of $\mathrm{Ca}^{2+}$ in the fruit $(r=0.8)$, and positive correlation between $\left[\mathrm{Ca}^{2+}\right]$ in the mid and distal sections $(r=$ 0.84 ) of the fruit.

\section{Discussion}

This study demonstrates that fruit $\mathrm{Ca}^{2+}$ accumulation increased despite differences

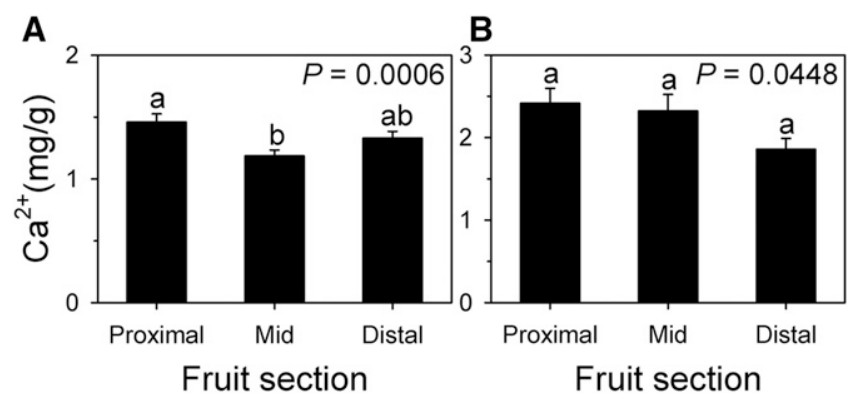

Fig. 4. Calcium concentration in proximal, mid, and distal sections at the marketable green fruit stage collected from the field in 2017 (A) and 2018 (B). Because interactions among varieties and sections were not significant, means were averaged from seven varieties (2017) and two varieties (2018). Values are means and SE of three (2017) and four (2018) replicates. Means separation was performed using Tukey's honestly significant difference following a test of significance using an analysis of variance $(\alpha=0.05)$. Means followed by a different letter are significantly different.

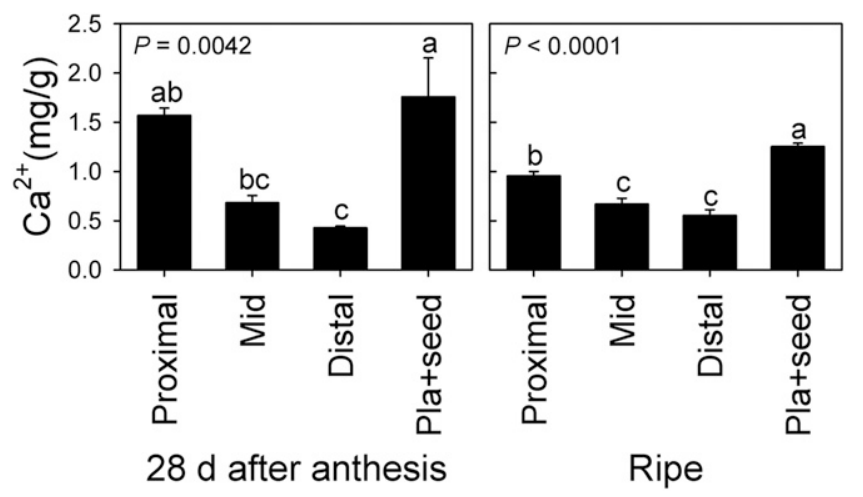

Fig. 5. Calcium concentrations in proximal, mid, distal, and internal [placenta (pla) + seed] sections at $28 \mathrm{~d}$ after anthesis (DAA) and ripe stage from 'Aristotle' in the greenhouse study. Values are means and SE of four replicates. Means separation was performed using Tukey's honestly significant difference following a test of significance using an analysis of variance $(\alpha=0.05)$. Means followed by a different letter are significantly different. fruit $\left[\mathrm{Ca}^{2+}\right]$ decreased during rapid growth; however, in this case, the $\left[\mathrm{Ca}^{2+}\right]$ declined throughout fruit development (Kalcsits et al., 2017; Miqueloto et al., 2014). The differences in the patterns of fruit $\left[\mathrm{Ca}^{2+}\right]$ during the post-cell expansion phase in this study (an increase in $\left[\mathrm{Ca}^{2+}\right]$ in the field in $2018 \mathrm{com}-$ pared to a more sustained decrease in the greenhouse) may be due to environmental and production-related factors. The maximum and minimum daily temperatures were similar at $29^{\circ} \mathrm{C}$ and 15 to $17^{\circ} \mathrm{C}$, respectively, in the field and greenhouse in this study. However, other factors such as light and irrigation frequency, which differed between the two sets of studies, have been demonstrated to affect fruit $\mathrm{Ca}^{2+}$ uptake in peppers (Ho et al., 1993; Marcelis and Ho, 1999; Silber et al., 2005). Furthermore, differences in fruit $\mathrm{Ca}^{2+}$ uptake patterns in this study may have been reflective of the current or recent status of $\mathrm{Ca}^{2+}$ availability. In our field experiments, because the different fruit size classes were all collected at the same time, it is likely that $\left[\mathrm{Ca}^{2+}\right]$ was uniform across the different size classes of 'PS09979325'. In contrast the greenhouse study may have captured the developmental pattern of fruit $\mathrm{Ca}^{2+}$ uptake into pepper fruit.

In the case of other macro- and micronutrients, in the field study, inconsistent patterns during fruit development were observed between the two varieties. However, in the greenhouse study, the concentration of almost all elements followed a pattern similar to that of $\mathrm{Ca}^{2+}$, where it continuously declined during fruit development. As with fruit $\left[\mathrm{Ca}^{2+}\right]$, this may be a reflection of the dilution effect during cell expansion. As mentioned, with regard to fruit $\left[\mathrm{Ca}^{2+}\right]$, differences in other elements between field varieties and the greenhouse study may reflect nutritional availability at the time of sampling, environmental variables, or production-related factors. In apples, fruit $\left[\mathrm{Ca}^{2+}\right]$ and $[\mathrm{K}]$ were similar but $[\mathrm{N}]$ and $[\mathrm{P}]$ differed during fruit development (Miqueloto et al., 2014). In tomato, a transient decrease in fruit $\left[\mathrm{Ca}^{2+}\right]$ but relatively consistent $[\mathrm{K}],[\mathrm{P}]$, and $[\mathrm{N}]$ were reported throughout development. Therefore, this study concluded differences in the import between $\mathrm{Ca}^{2+}$ and other macronutrients (Ehret and Ho, 1986b). However, due to the inconsistent patterns of nutrient accumulation, a comparison of fruit uptake patterns between $\left[\mathrm{Ca}^{2+}\right]$ and other macronutrients was difficult to interpret in this study.

In our study, fruit $\mathrm{Ca}^{2+}$ accumulation increased in fruits throughout fruit development

Table 5. Elemental concentrations in proximal, mid, and distal sections at the marketable green fruit stage collected from the field in 2018.

\begin{tabular}{|c|c|c|c|c|c|c|c|c|c|c|c|}
\hline \multirow[b]{2}{*}{ Section } & $\mathrm{K}$ & $\mathrm{Mg}$ & $\mathrm{P}$ & $\mathrm{N}$ & $\mathrm{S}$ & B & $\mathrm{Cu}$ & $\mathrm{Fe}$ & $\mathrm{Mn}$ & $\mathrm{Na}$ & $\mathrm{Zn}$ \\
\hline & \multicolumn{5}{|c|}{$(\mathrm{mg} / \mathrm{g})$} & \multicolumn{6}{|c|}{ (ug/g) } \\
\hline$\overline{\text { Proximal }}$ & 47.9 & $2.2 \mathrm{~b}$ & 4.8 & 30.1 & 3.4 & $16.8 \mathrm{c}$ & 23.2 & 91.9 & $19.6 \mathrm{~b}$ & 142.5 & $39.3 \mathrm{~b}$ \\
\hline Mid & 47.6 & $2.6 \mathrm{ab}$ & 5.3 & 29.7 & 3.7 & $20.1 \mathrm{~b}$ & 25.9 & 105.7 & $25.0 \mathrm{a}$ & 238.8 & $50.6 \mathrm{a}$ \\
\hline Distal & 49.7 & $2.8 \mathrm{a}$ & 5.4 & 31.9 & 3.6 & $23.7 \mathrm{a}$ & 26.7 & 103.2 & $26.6 \mathrm{a}$ & 137.2 & $51.1 \mathrm{a}$ \\
\hline Prob $>F$ & NS & 0.007 & NS & NS & NS & 0.0002 & NS & NS & 0.003 & NS & 0.0002 \\
\hline
\end{tabular}

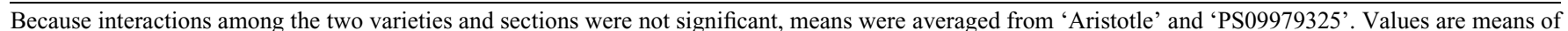

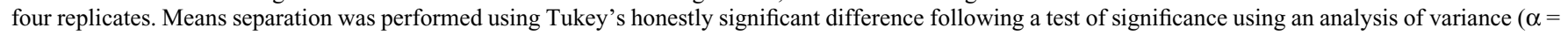
0.05). Means followed by a different letter are significantly different. NS = nonsignificant. 
Table 6. Elemental concentrations in proximal, mid, distal, and internal [placenta (pla) + seed] sections at $28 \mathrm{~d}$ after anthesis (DAA) and ripe stage from 'Aristotle'.

\begin{tabular}{|c|c|c|c|c|c|c|c|c|c|c|c|}
\hline \multirow[b]{2}{*}{ Section } & $\mathrm{K}$ & $\mathrm{Mg}$ & $\mathrm{P}$ & $\mathrm{N}$ & $\mathrm{S}$ & $\mathrm{B}$ & $\mathrm{Cu}$ & $\mathrm{Fe}$ & $\mathrm{Mn}$ & $\mathrm{Na}$ & $\mathrm{Zn}$ \\
\hline & \multicolumn{5}{|c|}{$(\mathrm{mg} / \mathrm{g})$} & \multicolumn{6}{|c|}{ (ug/g) } \\
\hline \multicolumn{12}{|l|}{$28 \mathrm{DAA}$} \\
\hline Proximal & $23.8 \mathrm{~b}$ & $1.8 \mathrm{ab}$ & $3.2 \mathrm{~b}$ & 18.3 & $2 \mathrm{~b}$ & 19.3 & $3.1 \mathrm{ab}$ & 32.6 & $29.2 \mathrm{a}$ & $84.1 \mathrm{~b}$ & 19.6 \\
\hline Mid & $24.4 \mathrm{~b}$ & $1.6 \mathrm{~b}$ & $3.3 \mathrm{~b}$ & 17.9 & $2 b$ & 19.1 & $3.2 \mathrm{ab}$ & 36.7 & $18.2 \mathrm{~b}$ & $101.5 \mathrm{ab}$ & 21.3 \\
\hline Distal & $33.4 \mathrm{a}$ & $1.6 \mathrm{~b}$ & $4.1 \mathrm{a}$ & 19.7 & $2.2 \mathrm{a}$ & 21.1 & $3.5 \mathrm{a}$ & 40.3 & $15.6 \mathrm{~b}$ & $80.3 \mathrm{~b}$ & 22.8 \\
\hline $\mathrm{Pla}+$ seed & $23 \mathrm{~b}$ & $2 \mathrm{a}$ & $3.5 \mathrm{~b}$ & 24.7 & $2.2 \mathrm{a}$ & 17.7 & $2.5 \mathrm{~b}$ & 45.5 & $27 \mathrm{a}$ & $131 \mathrm{a}$ & 23.2 \\
\hline Prob $>F$ & 0.0002 & 0.008 & 0.0025 & NS & 0.004 & NS & 0.0174 & NS & 0.0002 & 0.0279 & NS \\
\hline \multicolumn{12}{|l|}{ Ripe } \\
\hline Proximal & $23.2 \mathrm{~b}$ & $1.3 \mathrm{c}$ & $3.1 \mathrm{c}$ & $23.4 \mathrm{~b}$ & $1.9 \mathrm{c}$ & $15.3 \mathrm{~b}$ & $2.5 \mathrm{~b}$ & $38.7 \mathrm{~b}$ & $17.5 \mathrm{~b}$ & $72.2 \mathrm{~b}$ & $20 \mathrm{c}$ \\
\hline Mid & $23.6 \mathrm{~b}$ & $1.5 \mathrm{bc}$ & $3.2 \mathrm{c}$ & $23 \mathrm{~b}$ & $2 \mathrm{bc}$ & $16.5 \mathrm{ab}$ & $2.9 \mathrm{ab}$ & $44.4 \mathrm{~b}$ & $20.8 \mathrm{~b}$ & $65.4 \mathrm{~b}$ & $25 \mathrm{~b}$ \\
\hline Distal & $29.2 \mathrm{a}$ & $1.6 \mathrm{~b}$ & $3.7 \mathrm{~b}$ & $27.5 \mathrm{~b}$ & $2.1 \mathrm{~b}$ & $20 a$ & $3.5 \mathrm{a}$ & $43.5 \mathrm{~b}$ & $20.7 \mathrm{a}$ & $59.5 \mathrm{~b}$ & $26.8 \mathrm{~b}$ \\
\hline Pla + seed & $22.4 \mathrm{~b}$ & $1.8 \mathrm{a}$ & $4.2 \mathrm{a}$ & $38 \mathrm{a}$ & $2.7 \mathrm{a}$ & $14.4 \mathrm{~b}$ & $3.3 \mathrm{a}$ & $60.6 \mathrm{a}$ & $19.2 \mathrm{ab}$ & $114.8 \mathrm{a}$ & $30 \mathrm{a}$ \\
\hline Prob $>F$ & 0.0003 & $<0.0001$ & $<0.0001$ & 0.003 & $<0.0001$ & 0.0033 & 0.0068 & $<0.0001$ & 0.0202 & 0.0029 & $<0.0001$ \\
\hline
\end{tabular}

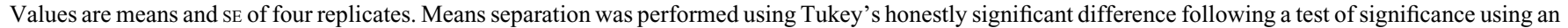
analysis of variance $(\alpha=0.05)$. Means followed by a different letter are significantly different. NS $=$ nonsignificant.

Table 7. Correlation of fruit $\left[\mathrm{Ca}^{2+}\right]$ and total amount to blossom-end rot (BER) incidence.

\begin{tabular}{|c|c|c|c|c|c|c|}
\hline & BER \% & Proximal $\left[\mathrm{Ca}^{2+}\right](\mathrm{mg} / \mathrm{g})$ & $\mathrm{Mid}\left[\mathrm{Ca}^{2+}\right](\mathrm{mg} / \mathrm{g})$ & Distal $\left[\mathrm{Ca}^{2+}\right](\mathrm{mg} / \mathrm{g})$ & {$\left[\mathrm{Ca}^{2+}\right](\mathrm{mg} / \mathrm{g})$} & Total $\mathrm{Ca}^{2+}(\mathrm{mg} /$ fruit $)$ \\
\hline BER \% & & -0.10 & -0.62 & -0.31 & -0.38 & -0.21 \\
\hline Proximal $\left[\mathrm{Ca}^{2+}\right](\mathrm{mg} / \mathrm{g})$ & 0.838 & & 0.56 & 0.37 & 0.76 & 0.80 \\
\hline $\operatorname{Mid}\left[\mathrm{Ca}^{2+}\right](\mathrm{mg} / \mathrm{g})$ & 0.141 & 0.188 & & 0.84 & 0.93 & 0.68 \\
\hline Distal $\left[\mathrm{Ca}^{2+}\right](\mathrm{mg} / \mathrm{g})$ & 0.505 & 0.416 & 0.018 & & 0.87 & 0.70 \\
\hline$\left[\mathrm{Ca}^{2+}\right](\mathrm{mg} / \mathrm{g})$ & 0.399 & 0.049 & 0.002 & 0.011 & & 0.86 \\
\hline Total $\mathrm{Ca}^{2+}$ (mg/fruit) & 0.650 & 0.032 & 0.091 & 0.081 & 0.013 & \\
\hline
\end{tabular}

Correlations are shown above the diagonal and $P$ values $(\alpha=0.05)$ are shown below the diagonal. Significant correlations and $P$ values are shown in bold.

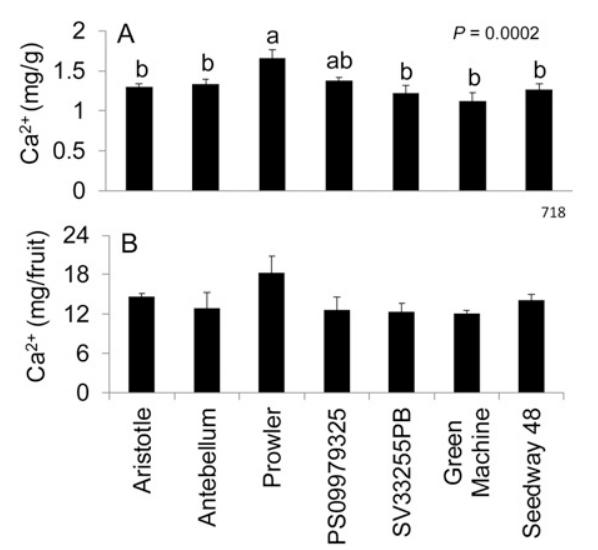

Fig. 6. Calcium concentration (A) and amount per fruit (B) and in marketable green fruit in seven varieties collected from the field in 2017. Values are means and SE of three replicates. Means separation was performed using Tukey's honestly significant difference following a test of significance using an analysis of variance $(\alpha=$ 0.05 ). Means followed by a different letter are significantly different.

with increasing fruit diameter in all the three experiments. Similarly, in tomato, even though fruit $\left[\mathrm{Ca}^{2+}\right]$ showed a transient decrease during fruit development, $\mathrm{Ca}^{2+}$ accumulation continuously increased until ripening (Ehret and Ho, 1986b; Ho and White, 2005). An increase in overall fruit $\mathrm{Ca}^{2+}$ accumulation during fruit development has also been noted in avocado, grapes, and apples (Cocucci et al., 1990; Rogiers et al., 2006; Witney et al., 1986). In fact, absorption of fruit $\mathrm{Ca}^{2+}$ throughout fruit development has been demonstrated in apple, with the recommendation to apply this nutrient frequently, but

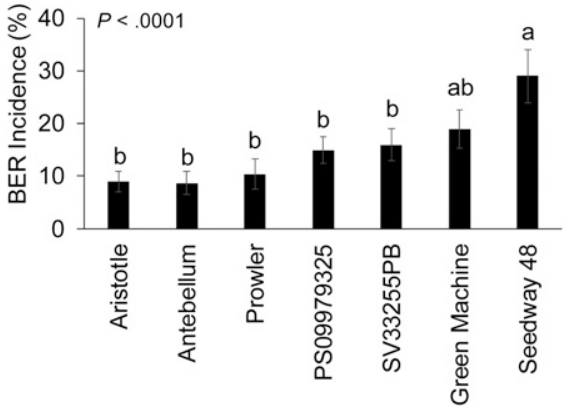

Fig. 7. Blossom-end rot (BER) incidence in marketable green fruit in seven varieties collected from the field in 2017. Values are means and SE of three replicates. Means separation was performed using Tukey's honestly significant difference following a test of significance using an analysis of variance $(\alpha=0.05)$. Means followed by a different letter are significantly different.

in reduced concentrations during fruit development to decrease bitter pit incidence (Kalcsits et al., 2017). The ability of bell pepper fruit to continuously uptake $\mathrm{Ca}^{2+}$ suggests that there is continuous demand for it during fruit development and, thus, its applications during fruit growth can be optimized in the field. Consistently, Coolong et al. (2019) reported a decrease in BER in bell pepper that received low levels of $\mathrm{Ca}^{2+}$ via fertigation throughout growth. These studies, along with the work reported here, indicate that optimizing $\mathrm{Ca}^{2+}$ application during the onset of fruit development may potentially reduce BER in pepper.

Similar to $\mathrm{Ca}^{2+}$, there was continued accumulation of all macro- and microelements in the fruit in field and greenhouse studies. In low-transpiring organs such as fruit, uptake of elements depends on their mobility in the phloem, with $\mathrm{K}, \mathrm{Mg}, \mathrm{P}, \mathrm{S}, \mathrm{N}$, and $\mathrm{Na}$ being more phloem-mobile than $\mathrm{Cu}$, $\mathrm{Fe}, \mathrm{Zn}, \mathrm{Ca}^{2+}$, and $\mathrm{Mn}$, whereas $\mathrm{B}$ is variably mobile depending on the species (Brown et al., 2002; Marschner, 1995; White and Brown, 2010). Furthermore, during early fruit development, xylem connectivity to several fruits is generally thought to contribute to only $\approx 10 \%$ to $24 \%$ of flux to the organ, whereas the remainder is supplied by the phloem; the xylem contribution further decreases during later stages of development (Drazeta et al., 2004; Ehret and Ho., 1986a; Ho et al., 1987; Lang and Ryan, 1994). Therefore, the increase in phloemmobile nutrients in this study was expected. However, the increase in relatively immobile elements such as $\mathrm{Ca}^{2+}$ and $\mathrm{Mn}$ during fruit development suggests that substantial xylem connectivity persists throughout fruit development in bell pepper.

Initiation of BER symptoms generally occurs at the distal portion of the fruit (Ehret and Ho, 1986b; Ho and White, 2005). In tomato, a decrease in the number and density of xylem vessels in the distal part of the fruit may explain lower $\mathrm{Ca}^{2+}$ transport specifically to this location (Adams and Ho, 1992; Ho et al., 1993). In this study, $\left[\mathrm{Ca}^{2+}\right]$ was significantly lower in the distal section of the fruit in the greenhouse study, with a similar trend in the field study in 2018. However, in $2017,\left[\mathrm{Ca}^{2+}\right]$ was similar among different sections of the fruit. Furthermore, a correlation analysis indicated a positive correlation between $\left[\mathrm{Ca}^{2+}\right]$ in the mid and basal sections of the fruit; however, fruit $\left[\mathrm{Ca}^{2+}\right]$ did not correlate with the BER incidence. One of the likely reasons for the discrepancy between $\left[\mathrm{Ca}^{2+}\right]$ in various fruit sections across the three 
studies may be the sampling of the entire fruit for $\left[\mathrm{Ca}^{2+}\right]$ in 2017 compared with only the pericarp tissue in 2018. Similarly, in pepper, $\left[\mathrm{Ca}^{2+}\right]$ was higher in pericarp tissue in fruit displaying lower growth rates; however, these differences were not evident when pericarp and seeds were pooled together (Marcelis and Ho, 1999). Tissue-specific patterns in $\mathrm{Ca}^{2+}$ accumulation have been observed for the rind and flesh tissue in watermelon (Bernadac, et al., 1996). In future studies, it is important to determine localized cellular calcium deficiency by investigating subcellular $\left[\mathrm{Ca}^{2+}\right]$ partitioning in fruit sections (de Freitas et al., 2011). Furthermore, the lack of a direct link between $\left[\mathrm{Ca}^{2+}\right]$ deficiency and the BER incidence in several studies also suggests a role for antioxidant levels in the distal part of the fruit in the development of BER symptoms (Hagassou et al., 2019; Nonami et al., 1995; Rached et al., 2018; Saure, 2001).

In this study, with the exception of [Mn], the concentration of almost all other macronutrients and micronutrients had a trend opposite that of $\left[\mathrm{Ca}^{2+}\right]$, being higher in the distal end of the fruit compared with the proximal end; this distinction was more evident in the greenhouse study. The opposite trends between $\mathrm{Ca}^{2+}$ and the other relatively phloemmobile elements in this study suggest a higher phloem-to-xylem ratio at the distal end in bell pepper fruit. Another explanation is simply that fruit expansion at the distal end is lesser than the proximal end, suggesting a greater dilution effect in phloem-mobile elements in the proximal end compared with the distal end. Furthermore, comparisons of [Mn] and $\left[\mathrm{Ca}^{2+}\right]$, both of which are relatively immobile, specifically in the greenhouse study, indicated that similar to $\left[\mathrm{Ca}^{2+}\right],[\mathrm{Mn}]$ was dramatically lower in the distal section of the fruit compared with the proximal section at 28 DAA. This supports a more dysfunctional xylem at the distal end of the fruit. An indepth investigation of the contribution of xylem and phloem development and transport in relation to spatial nutrient homeostasis is required in future studies.

Interestingly, in this study, placenta and seed tissues displayed higher $\left[\mathrm{Ca}^{2+}\right]$ than mid and basal sections of the fruit pericarp. Similarly, grapes contained higher $\left[\mathrm{Ca}^{2+}\right]$ in seeds compared with the fruit flesh (Rogiers et al., 2006). Across multiple fruit crops, $\left[\mathrm{Ca}^{2+}\right]$ in the pedicel was reported to be 3- to 10-times higher than in the fruit, suggesting either a bottleneck in $\mathrm{Ca}^{2+}$ transport to the fruit or remobilization of $\mathrm{Ca}^{2+}$ from the pedicel to the fruit (Song et al., 2018). In future studies, spatial exploration of $\mathrm{Ca}^{2+}$ partitioning in peduncle, seed, and placental tissue will be necessary to determine if a similar bottleneck occurs in $\mathrm{Ca}^{2+}$ translocation to the bell pepper fruit pericarp tissue. This may also be true for several other macro- and microelements such as [Mg], [P], [N], [S], [Fe], [Na], and [Zn], which were the highest in the placenta and seed.

In conclusion, this is the first study to show that calcium accumulation occurs throughout fruit growth and development in bell pepper. This knowledge may allow for optimizing calcium application during fruit development to minimize symptoms of BER. An analysis of pericarp tissue showed that the distal section had lower $\left[\mathrm{Ca}^{2+}\right]$ than the proximal section. The placenta and seeds had the highest amounts of $\mathrm{Ca}^{2+}$ and other macro- and micronutrients, which may suggest a bottleneck in translocation of nutrients to the fruit pericarp. Therefore, this study provides the foundation for future in-depth studies of temporal and spatial relationships between $\left[\mathrm{Ca}^{2+}\right]$ and bell pepper fruit growth and development.

\section{Literature Cited}

Adams, P. and L.C. Ho. 1992. The susceptibility of modern tomato cultivars to blossom-end rot in relation to salinity. J. Hort. Sci. 67:827-839.

Adams, P. and L.C. Ho. 1993. Effects of environment on the uptake and distribution of calcium in tomato and on the incidence of blossom-end rot. Plant Soil 154:127-132.

Belda, R.M. and L.C. Ho. 1993. Salinity effect on the network of vascular bundles during tomato fruit development. J. Hort. Sci. 68:557-564.

Bernadac, A., I. Jean-Baptiste, G. Bertoni, and P. Morard. 1996. Changes in calcium contents during melon (Cucumis melo L.) fruit development. Scientia Hort. 66:181-189.

Brown, P.H., N. Bellaloui, M.A. Wimmer, E.S Bassil, J. Ruiz, H. Hu, H. Pfeffer, F. Dannel, and V. Römheld. 2002. Boron in plant biology. Plant Biol. 4:205-223.

Casero, T., E. Torres, S. Alegre, and I. Recasens. 2017. Macronutrient accumulation dynamics in apple fruits. J. Plant Nutr. 40:2468-2476.

Cocucci, S., A. Abruzzese, E. Rizzi, I. Mignani, and C.P. Treccani. 1990. Fruit development, calcium level and bitter pit in apple. Adv. Hort. Sci. 3:147-150.

Coolong, T., A.L.B.R. da Silva, and J. Shealey. 2019. Fertilizer program impacts yield and blossom end-rot in bell pepper. HortTechnology 29:163-169.

de Freitas, S.T., M. Padda, Q. Wu, S. Park, and E.J. Mitcham. 2011. Dynamic alterations in cellular and molecular components during blossom-end rot development in tomatoes expressing $s C A X 1$, a constitutively active $\mathrm{Ca}^{2+} / \mathrm{H}^{+}$antiporter from Arabidopsis. Plant Physiol. 156:844-855.

Drazeta, L., A. Lang, A.J. Hall, R.K. Volz, and P.E. Jameson. 2004. Causes and effects of changes in xylem functionality in apple fruit. Ann. Bot. 93:275-282.

Ehret, D.L. and L.C. Ho. 1986a. Effects of osmotic potential in nutrient solution on diurnal growth of tomato fruit. J. Expt. Bot. 37:1294-1302.

Ehret, D.L. and L.C. Ho. 1986b. Translocation of calcium in relation to tomato fruit growth. Ann. Bot. 58:679-688.

Ferguson, I.B. and C.B. Watkins. 1989. Bitter pit in apple fruit. Hort. Rev. 11:289-355.

Gilliham, M., M. Dayod, B.J. Hocking, B. Xu, S.J. Conn, B.N. Kaiser, R.A. Leigh, and S.D. Tyerman. 2011. Calcium delivery and storage in plant leaves: Exploring the link with water flow. J. Expt. Bot. 62:2233-2250.

Hagassou, D., E. Francia, D. Ronga, and M. Buti. 2019. Blossom end-rot in tomato (Solanum lycopersicum L.): A multi-disciplinary overview of inducing factors and control strategies. Scientia Hort. 249:49-58.

Ho, L.C. 1989. Environmental effects on the diurnal accumulation of ${ }^{45} \mathrm{Ca}$ by young fruit and leaves of tomato plants. Ann. Bot. 63:281-288.

Ho, L.C., R. Belda, M. Brown, J. Andrews, and P. Adams. 1993. Uptake and transport of calcium and the possible causes of blossom-end rot in tomato. J. Expt. Bot. 44:509-518.

Ho, L.C., R.I. Grange, and A.J. Picken. 1987. An analysis of the accumulation of water and dry matter in tomato fruit. Plant Cell Environ. 10:157-162.

Ho, L.C. and P.J. White. 2005. A cellular hypothesis for the induction of blossom-end rot in tomato fruit. Ann. Bot. 95:571-581.

Hocking, B., S.D. Tyerman, R.A. Burton, and M. Gilliham. 2016. Fruit calcium: Transport and physiology. Front. Plant Sci. 7:569.

Horton, D. 2016. Georgia pest management handbook. Univ. Georgia Coop. Ext. Serv. Spec. Bul. 28. 30 Apr. 2020.<https://site.caes.uga.edu/ vegpath/files/2016/06/GA-Pest-ManagementHandbook-2016-Commercial-Cotton-CornSoybeans-Sorghum-Peanuts-Sugarcane-SunflowersTobacco-Vegetables-Fruit-Pecans.pdf $>$.

Kalcsits, L., G. van der Heijden, M. Reid, and K. Mullin. 2017. Calcium absorption during fruit development in 'Honeycrisp' apple measured using ${ }^{44} \mathrm{Ca}$ as a stable isotope tracer. HortScience 52:1804-1809.

Kissel, D.E. and L. Sonon. 2008. Soil test handbook for Georgia. Univ. Georgia Coop. Ext. Special Bul. 62. 30 Apr. 2020. <https://secure.caes.uga.edu/extension/publications/files/pdf/SB\%2062_2.PDF>.

Lang, A. and K.G. Ryan. 1994. Vascular development and sap flow in apple pedicels. Ann. Bot. 74:381-388.

Marcelis, L.F.M. and L.C. Ho. 1999. Blossom-end rot in relation to growth rate and calcium contents in fruits of sweet pepper (Capsicum annuum L.). J. Expt. Bot. 50:357-363.

Marschner, H. 1995. Mineral nutrition of higher plants. 2nd ed. Academic Press, London.

Marti, H.R. and H.A. Mills. 1991. Calcium uptake and concentration in bell pepper plants as influenced by nitrogen form and stages of development. J. Plant Nutr. 14:1177-1185.

Miqueloto, A., C.V.T. do Amarante, C.A. Steffens, A. dos Santos, and E. Mitcham. 2014. Relationship between xylem functionality, calcium content and the incidence of bitter pit in apple fruit. Scientia Hort. 165:319-323.

Montanaro, G., B. Dichio, and C. Xiloyannis. 2010. Significance of fruit transpiration on calcium nutrition in developing apricot fruit. J. Plant Nutr. Soil Sci. 173:618-622.

Montanaro, G., B. Dichio, C. Xiloyannis, and G. Celano. 2006. Light influences transpiration and calcium accumulation in fruit of kiwifruit plants (Actinidia deliciosa var. deliciosa). Plant Sci. 170:520-527.

Montanaro, G., B. Dichio, C. Xiloyannis, and A. Lang. 2012. Fruit transpiration in kiwifruit: Environmental drivers and predictive model. $\mathrm{AoB}$ Plants 2012:Pls036, doi:10.1093/aobpla/pls036.

Morley, P.S., M. Hardgrave, M. Bradley, and D.J. Pilbeam. 1993. Susceptibility of sweet pepper (Capsicum annum $\mathrm{L}$.) cultivars to the calcium deficiency disorder 'Blossom end rot', p. 563-567. In: M.A.C. Fragoso and M.L. van Beusichem (eds.). Optimization of plant nutrition. Kluwer Academic Publishers, Dordrecht, the Netherlands.

Nonami, H., T. Fukuyama, M. Yamamoto, L. Yang, and Y. Hashimoto. 1995. Blossom-end rot of tomato plants may not be directly caused by calcium deficiency. Acta Hort. 396:107-114.

Rached, M., B. Pierre, G. Yves, C. Matsukura, T. Ariizumi, H. Ezura, and N. Fukuda. 2018. Differences in blossom-end rot resistance in tomato cultivars is associated with total ascorbate rather than calcium concentration in the distal end part of fruits per se. Hort. J., doi: 10.2503/hortj.OKD-150.

Rogiers, S.Y., D.H. Greer, J.M. Hatfield, B.A. Orchard, and M. Keller. 2006. Mineral sinks within ripening grape berries (Vitis vinifera $\mathrm{L}$.). Vitis 45:115-123. 
Rubio, J.S., F. Garcia-Sanchez, F. Rubio, and V. Martinez. 2009. Yield, blossom-end rot incidence and fruit quality in pepper plants under moderate salinity are affected by $\mathrm{K}^{+}$and $\mathrm{Ca}^{2+}$ fertilization. Scientia Hort. 119:79-87.

Saure, M.C. 2001. Blossom-end rot of tomato (Lycopersicon esculentum Mill.)-a calcium or a stressrelated disorder? Scientia Hort. 90:193-208.

Saure, M.C. 2005. Calcium translocation to fleshy fruit: Its mechanism and endogenous control. Scientia Hort. 105:65-89.

Silber, A., M. Bruner, E. Kenig, G. Reshef, H. Zohar, I. Posalski, H. Yehezkel, D. Shmuel, S. Cohen, M. Dinar, E. Matan, I. Cohen, L. Karni, B. Aloni, and S. Assouline. 2005. High fertigation frequency and phosphorus level: Effects on summer-grown bell pepper growth and blossom-end rot incidence. Plant Soil 270:135-146.

Song, W., J. Yi, O.F. Kurniadinata, H. Wang, and X. Huang. 2018. Linking fruit $\mathrm{Ca}$ uptake capacity to fruit growth and pedicel anatomy, a cross-species study. Front. Plant Sci. 9:575.

Spurr, A.R. 1959. Anatomical aspects of blossomend rot in the tomato with special reference to calcium nutrition. Hilgardia 28:269-295.

Taylor, M.D. and S.J. Locascio. 2004. Blossom-end rot: A calcium deficiency. J. Plant Nutr. 27:123-139.

United States Department of Agriculture, National Agricultural Statistics Service (USDA-NASS). 2019. Crop Values 2018 Summary (April 2019). 30 Apr. 2020. <https://downloads.usda.library. cornell.edu/usda-esmis/files/k35694332/g445cn37b/ 8910k2787/cpv10419.pdf>.

Vegetable Crop Handbook for Southeastern United States. 2017. 30 Apr. 2020. <http://www.pesticidedatabase.com/guides-pdf $/ 2017 \% 20$ Southeastern \%20U.S.\%20Vegetable\%20Crop\%20Handbook.pdf $\%$.

White, P.J. and M.R. Broadley. 2003. Calcium in plants. Ann. Bot. 92:487-511.

White, P.J. and P.H. Brown. 2010. Plant nutrition for sustainable development and global health. Ann. Bot. 105:1073-1083.

Witney, G.W., B.N. Wolstenholme, and P.J. Hofman. 1986. Calcium accumulation in avocado fruits: Effect of cultivar and tree vigour. S. Afr. Avocado Growers' Assoc. Yrb. 9:39-42. 